\title{
"Walking Gently on the Earth": An Interview with Nana Firman on Islamic Environmental Ethics
}

\author{
Daniel Hummel \\ University of Michigan, Flint \\ Mohamed Daassa ${ }^{1}$ \\ University of Michigan, Flint
}

\begin{abstract}
This paper explores Islamic interpretations that contribute to understandings of the importance of protecting the environment and living a "green" lifestyle. These concepts are explored within the wider sphere of eco-theology. In addition to an exploration of these concepts in general, this paper specifically aims to understand how Muslims interpret their role in environmental stewardship. Its focus is an interview with Nana Firman, GreenFaith's Muslim director and the co-director of the Islamic Society of North America's Green Mosque Initiative. This interview provides the basis for explorations into a faith-based environmental activism in the Muslim American community.
\end{abstract}

\section{Introduction}

There is an increasing environmental awareness, a reality coupled with a consensus on human-induced climate change and its consequences. Recent mass

\footnotetext{
${ }^{1}$ Daniel Hummel, Ph.D., is an Assistant Professor in the Department of Political Science at the University of Michigan, Flint. He has published on Islamic history, civil rights, interfaith relations, and the building of mosques in the United States. In addition to this research, he has served on a mosque board and worked for an Islamic charity. He can be reached at dhummel@umflint.edu.

Mohamed Daassa is Lecturer IV in the Department of Foreign Languages \& History at the University of Michigan, Flint. In addition to having extensive experience working with immigrant communities in France and the U.S., he is a of the American Arab Heritage Council, the Flint Islamic Center, the Grand Blanc Islamic Center, Noor Unity Center, the Muslim House, the International Center for Greater Flint, and other regional organizations. He can be reached at daassa@umflint.edu.
} 
extinctions have caused alarm across the scientific community. Kolbert has written extensively about these extinctions, referring to them as the "sixth extinction," after five other known major extinctions in Earth's history. Thinking about humanity's ability to coexist with the environment, Kolbert laments that "though it might be nice to imagine there once was a time when man lived in harmony with nature, it's not clear that he ever really did" (Kolbert, 2015, p. 235).

The propensity to destroy the environment is equally matched by a great desire to preserve it. This desire is based within a value system that promotes an environment-friendly lifestyle. Some are inspired to action by warnings from the scientific community. Others are inspired by religious teachings and ethics to care for the environment and to protect nature. This article focuses on these ethics from an Islamic perspective.

These ethics are explored through an interview with Nana Firman, a prominent Muslim activist in the Muslim world who has been involved with environmental causes for more than a decade. A native of Indonesia who currently resides in the United States, she has found great inspiration in her faith for her efforts to defend the environment. Her words serve as further reinforcement of the concepts explored below.

This article explores the sources for faith-based "green," ethics including an early debate on whether religion inspires environment-friendly behavior. In the West, most of this debate has concerned Christianity. The first part of this paper explores this in the literature. Later characterizations of faith-based environmental perspectives have been termed "eco-theology." This eco-theology is explored in Islam.

\section{Literature}

The literature has delineated several key predictors for environmental beliefs and behaviors in the West. Those who are younger, better educated, and politically liberal tend to support pro-environment initiatives (Boyd, 1999; Liere \& Dunlap, 1980). In the past, this research either discounted the contributions of religion and religiosity or argued that they were actually detrimental to the environment.

Lynn White first argued that those of the Judeo-Christian creed were not environmentally conscious because the Bible taught a "dominate the earth" mentality, as can be seen in Genesis 1:28, where God instructs humanity to "fill the earth and subdue it." White argued that this did not teach coexistence with the environment, but its complete submission to humanity's will. Given the lack of knowledge of complex ecological systems, this attitude had disastrous effects, according to White. She went so far as to argue that the historical roots of the present-day environmental crisis are based within religion (White, 1967). 
White's thesis opened the door for further exploration of the connections between religion / religiosity and environmental attitudes. Some research confirmed her thesis (Biel \& Nilsson, 2005; Eckberg \& Blocker, 1996). For example, Sherkat and Ellison found that increased involvement in the church reduces serious consideration of environmental problems (2007) especially in the fundamentalist traditions of Christianity. Guth et al. noted that most of the denominations in the National Council of Churches had passed national resolutions on environmental issues at the time, except for those in the fundamentalist tradition (1993). The evangelical churches in this tradition have been divided over this topic. Despite this, Danielsen argued that most mainstream versions of these churches are "going green" (2013).

Other studies have found that religion encourages a pro-environment perspective (Kanagy \& Willits, 1993; Lowry, 1998). Boyd found that prayer predicted more "green behaviors" (1999). Sherkat and Ellison, who found that a belief in the Bible's inerrancy increased an environmental stewardship orientation, argued that unlike White's assertion, the Bible is replete with examples of pro-environment teachings. They cite the example of Noah and the Flood or specific verses like Matthew 10:29-30, which describe the all-knowing God who cares for His creatures (2007).

Research in this area has increased through the years due to "eco-theology," namely, theological perspectives on environmentalism. Similar to White, Folz, Denny, and Baharuddin argue that understanding the environment and caring for it requires an understanding of the its human inhabitants' religious life (2007). Science, as noted in many fields (e.g., public policy and political science) and to the chagrin of most scientists, does not satisfy mot people's needs and is rarely a motivator of change, for it neither answers existential questions nor considers any form of moral obligations to the future. Wallace describes these as the "so-what" questions. The purpose of life and any type of morals are absent from scientific considerations, unless one is considering the neurological sources of these beliefs (2012).

A transcendental value system rooted in religion encompasses higher intangible goods that. These goods are great motivators to change. This value system and pursuit of these goods help religious people become more authentically religious while also legitimizing the faith (Ellingson, Woodley, \& Paik, 2012). Authenticity and legitimacy are core attributes for effective change. One sees the value in protecting the environment because doing so garners the blessings of God. The pursuit of this goal is to express one's religiosity and achieve these blessings. Concordantly, this goal becomes more legitimate in their eyes than similar goals pursued by secular organizations in the same field.

Several core Christian theologians have articulated this perspective. Some of them, such as Thomas Berry, Calvin DeWitt, and Rosemary Reuther, became eco- 
theologians and transformed the environmental crisis into a cosmological one (Jenkins, 2009). The goals may be the same as similar secular organizations, but the perspective is entirely different.

Theological perspectives on this topic appeared in Christian communities in the 1970s and 1980s (Eaton, 2012) primarily in the United States, which also happens to be the most religious country among Western democracies. This movement flowered in the late 1990s with the development of three ethics of Christian environmentalism: stewardship, eco-justice (specifically focused on all forms of inequality), and eco-spirituality (with its return-to-nature emphasis) (Ellingson, Woodley, \& Paik, 2018).

The Islamic community had a similar awakening in the late 1990s. Muslims in the West were the first to articulate a modern environmental ethics in Islam based solely on the Qur'an and Sunnah. They cited verses that forbid despoiling the earth (7:85) and the emphasis to not spreading corruption in the land (28:77). The Qur'anic scholar Ibn Kathir (d. 1373) interpreted 28:77 to mean that the believer should "not let (his/her) aim be to spread corruption on the earth and do harm to Allah's creation” (“Quran Tafsir Ibn Kathir,” 2018).

In addition to specific Qur'anic verses, some members of the Muslim community have interpreted several terms as having "green" implications. One very frequent such term khalifa, which signifies the Islamic concept that humanity is Allah's viceroy on Earth. Within the context of environmentalism (Saniotis, 2011), this term is often translated as "stewardship," which is also one of the three ethics of environmentalism found in Christianity. Another oft-cited term in this regard is amāna, which has traditionally been translated as "rights and responsibilities" as they pertain to other people and the environment. However, it also means trust. As explained by Haneef, "technically, amāna is every right of one's responsibility either belonging to God or to that of humans or even to other creatures whether in work, words and belief. And in terms of its application, it practically stands for fulfilling one's responsibility in all dimensions of life and relationships" (2002). As it pertains to the environment, this means one's responsibilities to protect it from degradation.

Muslims in the West have been at the forefront of exploring these concepts as they pertain to the environment. The best known of these scholars are Mawil Iz al-Din, Seyyid Hossain Nasr, and Fazlun Khalid. During a 2015 interview, Nasr argued that the Qur'an refers more to the natural world than other scriptures within the monotheist traditions. Based on this, he recommended that a way must be found to reconnect Muslims with this concern for nature in order to avert an environmental crisis. He noted that in Muslim countries these concerns have been mostly secondary to economic development, but that there has been some change. He cited the landmark 2015 Islamic Declaration on Global Climate Change as one example. Still, he observed that Muslims do not think deeply on environmental 
issues and associate such concerns with garbage on the street, for example ("A religious nature," 2015; Foltz, 2000).

This observation has been confirmed in some research on this topic. For example, Rice found in Egypt in the early 2000s that even though religiosity was positively correlated with activist behavior regarding the environment, Egyptians typically constructed concerns about the environment around individual health and cleanliness. Concepts like țahara (purity in Islam) are typically used in this context; however, they are primarily applied to the individual and rarely to the larger environment (2006).

Despite these observations, environmental activism is popular in the Islamic world. In his comprehensive study, Fish found that Muslims participate in volunteer organizations at a lower rate than non-Muslims, with the exception of "active" memberships in environmental organizations. Although he found this to be a curious revelation, this activism could be rooted in an increasing awareness in the Muslim world regarding Qur'anic exhortations to be responsible and protect God's creation (Fish, 2011).

In an effort to understand how Muslims understand these ethics and how they shape their environmental activism, the next section includes an interview with Nana Firman, a prominent activist who was involved with the Islamic Declaration on Global Climate Change, has worked with the World Wildlife Fund, and is currently working with GreenFaith, an interfaith organization dedicated to mobilizing people of faith for environmental leadership. In addition to this, she has also been active with the Islamic Society of North America and its Green Masjid initiative.

\section{Interview with Nana Firman}

\section{Can you tell me about your background as it applies to your work currently on environmental issues? What is your current affiliation?}

I got my bachelor's degree in industrial design and my master's degree in urban design. I was an urban designer. That's how I got into environmental work. I was educated in the United States, but I worked as an urban designer in Indonesia. My work at that time was working with geologists. I learned a lot from them about the appropriate design of cities for disaster-prone areas, like [the one] where Indonesia is located.

When the tsunami happened in Aceh, Indonesia, in 2004 I was asked by the World Wildlife Fund (WWF) to evaluate the future of their programs in that area. I was tasked with developing reconstruction guidelines there. I ended up being the program manager for four years. People in Aceh just wanted to [re-]build fast, and at that time there was a scarcity of timber supplies. Around Aceh is [a] really 
dense forest, most of which was not touched during the decades-long conflict, so the idea [of] the people was to cut down the forest. This was a major challenge.

I ended up getting involved in protecting the forest [and], at the same time, making sure the reconstruction was done in a sustainable way. A lot of people did not understand what I was talking about. They only cared about rebuilding their homes as fast as possible. This was a major frustration for me. A friend approached me and suggested I engage with the people of Aceh on this topic from an Islamic perspective, since the people there are very religious. Around this time a colleague introduced me to Fazlun Khalid, who is the founder of the Islamic Foundation for Ecology and Environmental Sciences (IFEES). He suggested to me that we have a training program for ulama in Aceh. Despite having some issues [with] giving the presentation because of the restriction on women there, we found a way around it. Afterwards, I stressed with the ulama how memorizing the verses of the Qur'an that emphasize sustainable behavior is not enough. One has to practice it, too. This was a profound moment for the participants, as well as my future in this field. Later, I returned to the United States and began working with GreenFaith. I have been with them for the last five years as a fellow and their Muslim outreach coordinator.

\section{Who was the biggest influence on you to pursue this work, and why?}

I would say Fazlun Khalid. When I first met Fazlun, I did not realize how important he was to this line of work. He was my recommendation to GreenFaith, and they were amazed that I had worked with him in the past. It was at that moment that I realized how pivotal he was to this work. Besides him, I must also mention that my own mother was very environment-friendly and helped instill in me some of these "green" virtues. In addition, Prophet Muhammad (pbuh) is also a major influence on me because he was so "green" in his attitude to the environment.

\section{How does Islam inform you to be environmentally conscious and an advocate for environmental issues?}

Growing up Muslim, we tend to take things for granted with Islam. You don't really think about it. For example, the term khalif $a$ is usually constructed as a leader in the Muslim community, and this is how I understood it growing up. The more I learn, the term khalifa is actually more nuanced than that. It means the "vicegerent" and the "caretaker." And that is what we need to emphasize with this term. And even little things that are not as complex, like not wasting food or the hadith on eating the food that is close to you - we don't really think deeply about ... how these teachings have implications for sustainable living. 
We do not draw the connections about what we learn in Islam and the practicalities of the faith, especially as it pertains to the environment. For example, there is an a yah in the Qur'an that describes the act of walking gently on the earth, but few associate this verse with leaving a small ecological footprint. The interesting thing is that Zaid Shakir at Zaytuna College confirmed this interpretation, that this specifically emphasizes doing the least amount of damage to the environment while one is on the planet.

This is why I emphasize in my talks that when we die, according to the hadith, we only collect good deeds in the grave because of our righteous children, the knowledge you gave to others, and any charity that was used that still benefits people, such as the building of a mosque. We can also receive bad deeds if we spread mischief in the land and destroyed the earth while we were alive. I am so passionate about this work because of how closely related sustainable lifestyles are with my faith in Islam.

\section{Can you elaborate on your passion for this work?}

We, as Muslims, should not do this because we think it's "cool." Allah has given us the responsibility for this planet, so we need to take this responsibility seriously. The whole earth is the sign of our Creator. The word ayyat in Arabic means '“signs' which are used to describe the verses in the Qur'an. But it can also be used to describe the evidence for our Creator in the environment. Can you imagine if one $\bar{a} y \bar{a} t$ is taken away from the Qur'an? How would the Muslims react about that? But why don't we feel the same when a species goes extinct? That is one a yah for the sign of God which has been erased from the planet because of our behavior. Where is the outrage for this? Those are equal to me.

\section{Do you think that the emphasis on the environment is unique to Islam, or do other religions also share a similar concern?}

An interesting thing about working on faith-based environmental work [is that] you learn that other faiths also have similar exhortations to care for the earth. People of faith can differ on many issues, but when we talk about the environment we speak the same language. It doesn't matter [about] your faith or even if you don't have faith. Everyone wants clean air, clean water, and healthy food. It's a basic human need.

When people talk about the environment, they can find agreement. Our joke is that when multiple religious communities come together, we should only talk about the environment. From the different interfaith discussions that I have had, I found that many of our teachings are very similar to each other. For example, I was mentioning the hadith on planting trees even if tomorrow is the end of the 
world, and a Jewish rabbi spoke up and said that they also have that teaching in their religion.

\section{Are Muslims in the United States as environmentally conscious as non- Muslims? Why or why not?}

In my observations, when we bring environmental issues into the Muslim community, Muslims often times associate it with white people. There is a disconnection between the religion of Islam and what is being practiced in these communities. When I give presentations, I approach these environmental issues wholly from the Islamic perspective and they are quite surprised. That's why we need to be careful how we construct a narrative around these issues for these communities.

For example, one time I was visiting my friend in Portland, Oregon, and she was complaining about the city requiring her to do composting. Now, I knew she was a very observant Muslim so I described the law as very Islamic. She was taken aback by this because she did not see how Islam applied to that at all. After I explained this to her, I was invited to the local masjid to give a presentation on this. This helped the local Muslim community to understand the value of composting as well as educat[ed] them about how Islam teaches them to be environmentally friendly. The Muslims in that community became more accepting of the new law after that. You know, three or four years ago the Islamic Society of North America (ISNA) started the Green Masjid initiative, but now this has been broadened beyond the masjid to all aspects of our community through the Green Committee of ISNA. These are examples of how attitudes are changing in the Muslim community.

\section{Why do you think Muslim countries are not as environmentally conscious and/or protecting the environment as actively as Western countries?}

I see this as a developing world problem. They are trying to go as fast as possible to catch up with development. For me, I always questioned why must they follow the West. They can have their own standards or targets. The other thing is the shift in economic status with careers that are close to nature, like farmers not garnering as much respect as they used to in these countries. Many people in these countries are staying away from these careers.

When I introduced the concept of urban farming in Jakarta a few years ago, everyone laughed at me. Now people are beginning to do it. I also suggested that those living on the river bank, who are mostly poor, to use that land to grow things. The idea is that they are increasing their food security while also limiting the incentive to throw garbage on this land and in the river. Problems like these 
can often be solved in tandem. Every time I go back to Indonesia, I visit the offices of MUI (Majelis Ulama Indonesia) to seek their assistance with promoting these types of things. I am not a religious scholar, so I can't make a fatwa. I am only an activist, so I need them to be on board.

My sister works for the World Wildlife Fund in Indonesia (WWF-Indonesia) and also organizes talks where I speak to youth in Indonesia. They are often surprised that no one has ever talked about this topic with them. The "green" movement is growing in the Muslim world. It's a little bit difficult to talk to the older generations, but the youth are very interested in it. The change is mostly going to come from the minbar in the Islamic world.

I just spoke with Fazlun the other day, and he said that it is very tough in the Muslim world because they are facing so many other issues that the environment is not their priority. I try to remind them that [many] of these conflicts are over a lack of resources and that sustainable living can conserve them and potentially reduce these conflicts. Everything is connected, but for sure if the Earth is not livable, then these already pointless conflicts will be even more pointless. Things are changing. For example, a few years ago there was the Islamic Declaration on Global Climate Change. Our goal now is to make this declaration known throughout the Islamic world, which has already started to be implemented with transformations for the future.

\section{Discussion}

The interview with Firman highlights many elements of an Islamic environmental ethics. As discussed in the literature, Firman used the concept of khalifa to describe the role of people as "caretakers" of this planet. The most notable use of the term is found in Qur'an 2:30.

And (mention, O Muhammad), when your Lord said to the angels, "Indeed, I will make upon the earth a successive authority." They said, "Will You place upon it one who causes corruption therein and sheds blood, while we declare Your praise and sanctify You?" Allah said, "Indeed, I know that which you do not know." (Sahih International)

Here the translation of khalif $a$ is authority, which is how Firman understood the term before her environmental activism. Since then, her understanding of it has expanded to encompass its fuller aspects and, one might argue, the fuller aspects of leadership. A leader is both the authority for and caretaker of his/her community and, by extension, the environment. Firman has extended this beyond a central figure to all Muslims, who share a portion of this responsibility. Her 
example of not wasting food also has foundations in Qur'an 7:31: "O children of Adam, take your adornment at every masjid, and eat and drink, but be not excessive. Indeed, He likes not those who commit excess" (Sahih International).

Firman reinforces this individual responsibility by referring to the concept of sadaqa jāriya (continuing charity), an Islamic concept is found in the hadith (see, for example, Jāmi 'at-Tirmidhī, Vol. 3, Book 13, Hadith 1376). After death, a Muslim no longer has any ability to earn good deeds or bad deeds - except in the three cases she outlined in the interview. Firman explained that any residual effects from one's corruption also compound after death. Qur'an 7:38 describes this in how the nations enter hellfire, with one nation (the earlier nation) preceding the later nations because the earlier nations started the trend.

As discussed in the literature, science fails to provide a moral justification for "walking gently on the earth," as Firman noted in the interview. In Islam, the moral justification is captured by the concept of sadaqh jāriya. One can start positive trends or negative trends, but in Islam the reward for these does not end with death. The assumption here would be that a sustainable industry that does not violate the rights of others, including the right to clean water and clear air, will serve as an example to others who might choose a similar path. In Islam, the one who does this reaps those rewards even after death.

In the interview, Firman provides a powerful analogy between the $\bar{a} y \bar{a} t$ (signs) of the Qur'an and of nature. As she pointed out, $\bar{a} y \bar{a} t$ is traditionally translated as "signs" and the Qur'an's verses are considered signs of God's greatness. Similarly, God's greatness is shown through His creation. She questioned why Muslims are not outraged to the same degree when a species goes extinct due to human causes as would be the case if a verse were to be removed from the Qur'an.

Based on this explanation, Muslims have a strong impetus to protect the environment and the creatures living within it. If their preservation has that much spiritual relevance, then Muslims would be more environmentally conscious than any other religious community. This is especially true because Muslims have been found to be more religious than other communities (Jämi 'at-Tirmidhī, Vol. 3, Book 13, Hadith 1376).

Firman mentioned that there are some hurdles to making these connections in the Muslim community. For example, she stated that many Muslims in the United States associate environmental activism with "white people." This is likely the result of the segregated nature of social life among some Muslim communities in that country. However, activists like Firman are pushing this issue into the Muslim community from a faith-based perspective with ample evidence from the Qur'an and hadith. Her example of the composting law in Portland was particularly relevant to these changes. 
It is also interesting that a faith-based perspective on environmentalism seems to have risen across faiths at a similar time. As discussed in the literature, Christian environmental activism really started in the 1990s, which is also when Muslim environmental activism started in the West. As Firman pointed out, faith communities have more in common on environmental values and ethics than anything else. On the contrary, as Nasr said in his 2015 interview, Islam has a firmer stand on these values and ethics than any of the other monotheistic faiths. In fact, this is why the dissonance between her understanding of these values and ethics and actual practice in the Muslim community is most interesting.

Firman not only explained the potential cause of this in the Muslim American community, but also in the larger Muslim world. She observed that that world is largely focused on achieving economic development, one byproduct of which has been a discounting of traditional careers that tended to be more environmentally friendly, such as farming. Extreme poverty coupled with crowding in urban centers has contributed to environmental degradation.

The advice she has given to religious scholars, as well as to politicians and other community leaders in these countries, has not fallen on deaf ears. She felt that changes were slowly occurring, especially among the younger populations. Urban farming is no longer considered a negative activity with some adoption of this practice in Indonesia. Firman also felt confident that these changes will continue in the future, especially as the Islamic Declaration on Global Climate Change becomes better known throughout the Muslim world.

Nasr also mentioned this confidence in his 2015 interview when he observed that Saudi Arabia, for example, has had an environmental policy since the 1980s and that Pakistan created a National Conservation Strategy Unit in the 1990s. In addition, Iran has environmental protection written into its constitution (2015).

Concordantly, it appears that efforts at environmentally sustainable living are taking root in the Muslim world. The UAE is developing Masdar City, which is billed as the first fully sustainable city. Jordan is committed to have all of its mosques running on solar energy. Based on these developments, the beliefs of both Firman and Nasr seem to have reinforcement.

However, the centrality of Muslim religious leaders remains constant in Firman's explanations for environmental activism in the Muslim community. Noting the need for more progress, she explained that change will come from the minbar (pulpit). In other words, she is working with these figures in various countries to secure commitments to goals established in the Islamic Declaration on Global Climate Change.

The relevance of Islam to these discussions is the emphasis that it places on articulating those ethics and values that encourage a "green" lifestyle. As Firman pointed out in the interview, concepts such as khaliffa and $\bar{a} y \bar{a} t$ are useful to emphasize stewardship and the sanctification of the environment. Interestingly, 
she did not mention amāna, commonly translated as "trust" or țahāra, commonly translated as "purification," both of which also contribute to an Islamic environmental ethic.

It should be added that an academic discussion based within an exegetical approach to the Qur'an and hadìth, one that fully explores the sources and historical accounts, would be needed to confirm these relationships. There are problems with confirmation bias, meaning that one is looking to confirm one's own beliefs about environmental protection within the sacred texts of Islam. This approach is a double-edged sword, for particularly liberal interpretations of these terms to delineate Islamic environmental ethics and values could backfire with religiously conservative Muslims. Firman has expressly stated that she is not a religious scholar; however, she has emphasized that her interpretations have been confirmed by Islamic scholars such as Zaid Shakir.

Despite these concerns, delineating these ethics is crucial for establishing a sustainable and environmentally friendly practice and behavior in the Muslim community. Ethics and their accompanying values form the core of religion as well as of organizational and professional life. For example, one part of Islam is the maqāsid al-sharī' $a$ (the higher objectives [i.e., the principles or values] of the law. The classical Islamic scholar al-Ghazali (d. 1111) derived five general principles as protections in Islamic law: the protection of religion, life, intellect, family lineage, and wealth. Since then, others have expanded these protections, including the the Islamic scholar al-Shatibi's development of a theory of maqassid rooted in mașlaha (general wellbeing). At its core is the idea that every ruling in Islam is meant to achieve what is good and prevent what is harmful (Rane, 2013; Johnston, 2004; Auda, 2011).

This approach has allowed some flexibility in interpreting Islam as it applies to contemporary issues, including the present environmental crisis. For example, Al-Alwani (d. 2016) and al-Qaradawi (b. 1926)) developed the concept of fiqh alaqallīyāt, Islamic law for Muslims living in pre-dominantly non-Muslim societies. As Parray explains, "fiqh al-aqallizyatt, which deals with the daily problems that arise for millions of Muslim individuals living in the West, tries to reconcile conflicting practices with the culture and values of the host societies from within the framework of Islamic jurisprudence" (Parray, 2012). One might wonder if Firman, as a Muslim woman living in the West, has applied this approach in her interpretation of the environmental movement through the lens of Islam.

There are limits to this theoretical approach, however, because people are largely motivated by example. Firman indicated that she was inspired to pursue her work by Fazlun Khalid and motivated by Prophet Muhammad (pbuh), who she considers so "green." Highlighting the latter's "green" practices will have major ramifications for how Muslims interact with their environment. The more 
individuals adopt "green" behaviors potentially inspired by these examples, the more others will also adopt them as they follow their lead.

The hurdle, as illustrated by Firman, is convincing Muslims through an Islamic lens that protecting the environment should be a top priority. She pointed out that many of the issues facing the Islamic world have overlapping concerns with the environment, so that protecting it should not be mutually exclusive. There is a similar concern with Muslims living in the West, who are under increasing pressure due to prejudice. For example, the Institute for Social Policy and Understanding, a Muslim research organization that investigates issues related to Islam and the Muslim community, asked an open-ended policy prioritization question in its 2016 election year American Muslim poll. Overwhelmingly, the respondents' top priority was the economy and jobs, followed by bigotry and civil rights. In fact, Muslims were more concerned about bigotry and civil rights than any other demographic group in the poll. Environmental protection was not selected by any demographic group, including Muslims (Mogahed \& Pervez, 2016).

\section{Conclusion}

This article considers the intersection of religion and environmentalism. Specifically, it focuses on Islam and its environmental teachings as they are understood through eco-theological understandings of people's interaction with their environment. There is an increasing interest in this topic, especially as religion remains an important force in people's lives and within the public policy process. Ultimately, it is about what motivates people to do things that have both short-term and long-term implications.

Unlike in much of the Western world, with the exception of the United States, people in the Muslim world place great stock in their religion. Even in countries with supposedly secular regimes, Islam plays a prominent role in legislation and/or in the people's daily life. It is no surprise that Firman noted that change will come from the minbar, which is why she frequently interacts with ulama and masjids.

The Muslim world has many problems, a reality that she articulated as she heard it from Fazlun Khalid. Environmental protection is often at the lower end of social priorities. Still, Firman made the point that many of these problems in the Muslim world and elsewhere are due to environmental degradation. It seems appropriate that if Muslims are inspired most by their religion, then a thorough analysis of its environmental teachings will aid in individuals' adopting recommended "green" behaviors.

This paper is centered around an interview with an Islamic environmental activist in order to better understand some of Islam's environmental ethics and 
values that might inform its followers choices and behaviors. There is still a degree of risk associated with attempting to insert one's own objectives into Islam's actual teachings. Firman was already involved in environmental activism before she began using Islam to communicate this activism to Muslim audiences. It is always helpful to approach these teachings from a more objective lens.

Still, religion is lived, even if one wants to argue that there is an objective religious truth or an authentic message. Therefore, this interview reveals a great deal about how Muslims construct their environmentalism. It is telling that Firman found that interfaith interactions are more amicable when the topic is the environment. At the core, as she observed, everyone values clean water, air, and food - all basic necessities that bind people as well as instigate much conflict among them.

For those with an environmentally friendly message, Islam apparently has a robust set of concepts and teachings to facilitate this. At the very least, this interview shows this. One might also observe that there is a growing consensus in the Muslim community on some of the points that she raised. Her interaction with her friend and Portland's composting law is a good example of this.

This article is one effort to understand some of the ecotheological concepts in Islam. More research is needed to see how they are understood on a larger scale and the outcomes of these beliefs. Given the scientific consensus that humaninduced climate change is having a dire effect on the environment and the species living within it, including the human species, the impetus is there to understand social motivation for environmentally friendly behaviors. Religion is a major factor in this social motivation. This is especially true in the Muslim world, which now houses more than 1 billion people and continues to grow.

\section{References}

"A religious nature: Philosopher Seyyed Hossein Nasr on Islam and the environment." (2015). Bulletin of the Atomic Scientists 71(5), 13-18.

Auda, J. (2011). "A maqāșidī approach to contemporary application of the sharīah." Intellectual Discourse 19(2), 193-217. 
Biel, A., \& Nilsson, A. (2005). "Religious values and environmental concern: Harmony and detachment." Social Science Quarterly 86(1), 178-191.

Boyd, H. H. (1999). "Christianity and the environment in the American public." Journal for the Scientific Study of Religion 38(1), 36-44.

Danielsen, S. (2013). "Fracturing over creation care? Shifting environmental beliefs among Evangelicals, 1984-2010." Journal for the Scientific Study of Religion 52(1), 198-215.

Eaton, H. (2012). "Mapping ecotheologies: Deliberations on difference," Theology 116(1), 23-27.

Eckberg, D. L. and T. J. Blocker. (1996). "Christianity, environmentalism, and the theoretical problem of fundamentalism." Journal for the Scientific Study of Religion 35(4), 343-355.

Ellingson, S., Woodley, V. A., \& Paik, A. (2012). "The structure of religious environmentalism: Movement organizations, interorganizational networks, and collective action." Journal for the Scientific Study of Religion 51(2), 266-285.

Fish, M. S. (2011). Are Muslims distinctive?: A look at the evidence. New York: Oxford University Press.

Foltz, R. (2000). "Is there an Islamic environmentalism?" Environmental Ethics 22(1), 63-72.

Foltz, R. C., Denny, F. M., \& Baharuddin, A. H. (2007). Islam and ecology: A bestowed trust. Cambridge, MA: International Society for Science and Religion.

Guth,_J. L. et al., (1993). "Theological perspectives and environmentalism among religious activists." Journal for the Scientific Study of Religion 32(4), 373382.

Haneef, S. "Principles of environmental law in Islam." (2002). Arab Law Quarterly 17(3), 247.

Jenkins, W. J. "Religion and ecology: A review essay on the field." (2009). Journal of the American Academy of Religion 77 (1), 187-197.

Johnston, D. (2004). "A turn in the epistemology and hermeneutics of twentieth century ușūl al-fiqh." Islamic Law and Society 11(2), 233-282.

Kanagy, C. L., \& Willits, F K. (1993). “A 'greening' of religion? Some evidence from a Pennsylvania sample.” Social Science Quarterly 74(3), 674-683. 
Kolbert, E. (2015). The sixth extinction: An unnatural history. New York: Henry Holt \& Company,..

Liere, K. D., \& Dunlap, R. E. (1980). "The social bases of environmental concern: A review of hypotheses, explanations and empirical evidence." Public Opinion Quarterly 44(2), 181-197.

Lowry, R. C. (1998). "Religion and the demand for membership in environmental citizen groups." Public Choice 94(3/4), 223-240.

Mogahed, D., \& Pervez, F. (2016). American Muslim poll: Participation, priorities, and facing prejudice in the 2016 elections. Washington, DC: Institute for Social Policy and Understanding.

Parray, T. A. (2012). "The legal methodology of 'fiqh al-aqalliyyat' and its critics: An analytical study." Journal of Muslim Minority Affairs 32(1), 89.

“Quran Tafsir Ibn Kathir,” Guide US TV, accessed September 3, 2018, http://www.qtafsir.com/.

Rane, H. (2013). "The relevance of a maqasid approach for political Islam post Arab revolutions." Journal of Law and Religion 28(2), 489-520.

Rice, G. (2006). "Pro-environmental behavior in Egypt: Is there a role for Islamic environmental ethics?" Journal of Business Ethics 65(4), 373-390.

Saniotis, A. (2011). "Muslims and Ecology: Fostering Islamic Environmental Ethics," Contemporary Islam 6(2), 155-171.

Sherkat, D. E., \& Ellison, C. G. (2007). "Structuring the religion-environment connection: Identifying religious influences on environmental concern and activism.” Journal for the Scientific Study of Religion 46(1), 71-85.

Wallace, M. (2012). "A river runs through it: Mapping the sources and new directions of ecotheology." Theology 116(1), 31-35.

White, L. (1967). “The historical roots of our ecologic crisis.” Science 155(3767), 1203-1212. 